\title{
RNA Isolation
}

National Cancer Institute

\section{Source}

National Cancer Institute. RNA Isolation. NCI Thesaurus. Code C128789.

Any method that extracts RNA from biological samples, which includes the proper handling of biological samples prior to nucleic acid isolation, the separation of RNA from the rest of the components in the samples, and the storage of the RNA isolates. 